Langelaan, M., Boer, M.R. de, Nispen, R.M.A. van, Wouters, B., Moll, A.C., Rens, G.H.M.B. van. Change in quality of life after rehabilitation: prognostic factors for visually impaired adults.

International Journal of Rehabilitation Research: 2009, 32(1), 12-19

\begin{tabular}{|l|l|}
\hline $\begin{array}{l}\text { Postprint } \\
\text { Version }\end{array}$ & 1.0 \\
\hline Journal website & $\frac{\text { http://journals.Iww.com/intirehabilres/Abstract/2009/03000/Change in quality of }}{\frac{\text { life after rehabilitation .2.aspx }}{\text { http://www.ncbi.nlm.nih.gov/pubmed/19057390 }}}$ \\
\hline Pubmed link & $\underline{10.1097 / M R R .0 b 013 e 3283063503}$ \\
\hline DOI &
\end{tabular}

This is a NIVEL certified Post Print, more info at http://www.nivel.eu

\title{
Change in quality of life after rehabilitation: prognostic factors for visually impaired adults
}

\author{
LANGELAAN, MAAIKE ${ }^{\mathrm{ABCD}}$; DE BOER, MICHIEL R. ${ }^{\mathrm{ABE}}$; VAN NISPEN, RUTH M.A. ${ }^{\mathrm{A}}$; \\ WOUTERS, BILL ${ }^{\mathrm{C}}$; MOLL, ANNETTE C. ${ }^{\mathrm{AB}}$; VAN RENS, GER H.M.B. ${ }^{\mathrm{AB}}$ \\ ${ }^{a}$ Department of Ophthalmology \\ ${ }^{\mathrm{b}}$ Institute for Research in Extramural Medicine, VU University Medical Centre, Amsterdam \\ ${ }^{\mathrm{c}}$ Department of Research and Development, Visio Het Loo Erf, National Rehabilitation \\ Centre for Visually Impaired Adults, Apeldoorn \\ ${ }^{\mathrm{d}}$ Netherlands Institute for Health Services Research (NIVEL), Utrecht \\ ${ }^{\mathrm{e}}$ Faculty of Earth and Life Sciences, Free University of Amsterdam, Amsterdam \\ fDepartment of Ophthalmology, Elkerliek Hospital, Helmond, The Netherlands
}

\begin{abstract}
The overall aim of rehabilitation for visually impaired adults is to improve the quality of life and (societal) participation. The objectives of this study were to obtain the short-term and long-term outcome of a comprehensive rehabilitation programme on quality of life for visually impaired adults, and prognostic baseline factors responsible for differences in outcome between certain groups of patients. The questionnaire was administered to 129 visually impaired adults (mean age 42.1 years). Quality of life was measured with the Visual Functioning Questionnaire, developed by the National Eye Institute (NEI-VFQ-25). Measurements were conducted during the observational programme (baseline measurement), and 3 months and 1 year after finishing rehabilitation. The change between subsequent measurements of the four dependent variables was measured, and the longitudinal relationship between vision-related quality of life on the one hand and possible prediction factors on the other was evaluated by means of random coefficient analyses. If the factor scores 1 year after rehabilitation were compared with baseline scores, the Mental Health and Dependency scale showed a significant improvement. For participants who received rehabilitation, age seemed to be a significant prediction variable for all factors. Additionally, functional vision score, and time at onset of visual impairment were predictors for the factor 'Pain and Discomfort'. The results indicate that only age was a predictor for all domains of quality of life. Future research should aim at confirming these results. Ultimately, these findings should lead to adjustments in the rehabilitation programme.
\end{abstract}


Langelaan, M., Boer, M.R. de, Nispen, R.M.A. van, Wouters, B., Moll, A.C., Rens, G.H.M.B. van. Change in quality of life after rehabilitation: prognostic factors for visually impaired adults.

\begin{abstract}
Das übergreifende Ziel der Rehabilitation für sehbeeinträchtigte Erwachsene war die Verbesserung der Lebensqualität und der (gesellschaftlichen) Teilnahme. Die vorliegende Studie sollte das kurz- und langfristige Ergebnis eines umfangreichen Reha-Programms zur Lebensqualität für sehbeeinträchtigte Erwachsene erfassen sowie die Prognosefaktoren gegenüber Baseline, die für die unterschiedlichen Ergebnisse zwischen bestimmten Patientengruppen verantwortlich sind. Der Fragebogen wurde 129 sehbeeinträchtigten Erwachsenen im durchschnittlichen Alter von 42,1 Jahren unterbreitet. Die Lebensqualität wurde anhand des vom National Eye Institute (NEI-VFQ-25) entwickelten Visual Functioning-Fragebogens gemessen. Die Messungen erfolgten im Rahmen der Beobachtungsstudie (Messung gegenüber Baseline) sowie 3 Monate bzw. 1 Jahr nach Abschluss der Rehabilitation. Die Veränderungen zwischen den anschließenden Messungen der vier abhängigen Variablen wurden gemessen, und die longitudinale Beziehung zwischen der sehbedingten Lebensqualität einerseits und möglichen Prädiktivfaktoren andererseits wurde mittels randomisierten Koeffizientenanalysen beurteilt. Beim Vergleich der Skalenwerte für die Faktoren ein Jahr nach der Rehabilitation mit den Skalenwerten gegenüber Baseline wies die Mental Health and DependencySkala (seelische Gesundheit und Abhängigkeit) eine signifikante Verbesserung auf. Für die Reha-Teilnehmer schien das Alter eine signifikante PrädiktorVariable für alle Faktoren zu sein. Darüber hinaus waren auch der funktionelle Sehvermögens-Score und der zeitliche Eintritt der Sehbeeinträchtigung Prädiktoren für den Faktor Schmerz und Beschwerden“. Die Ergebnisse deuten darauf hin, dass nur das Alter ein Prädiktor für alle Bereiche der Lebensqualität ist. Künftige Forschungsprojekte sollten auf eine Bestätigung dieser Ergebnisse hinarbeiten. Letztendlich sollten diese Befunde Anpassungen im RehaProgramm nach sich ziehen.
\end{abstract}

\begin{abstract}
El objetivo general de la rehabilitación de adultos con trastornos de la visión consiste en mejorar su calidad de vida y participación social. Los objetivos de este estudio fueron valorar los resultados de un programa integral de rehabilitación a corto y a largo plazo relativos a la calidad de vida de adultos con trastornos de la visión y precisar los factores pronóstico presentes al inicio del tratamiento considerados responsables de las diferencias en los resultados entre determinados grupos de pacientes. Se aplicó el cuestionario a 129 adultos con trastornos de la visión (media de edad: 42,1 años). Para medir la calidad de vida se utilizó el cuestionario de funcionamiento visual (NEI-VFQ-25) del National Eye Institute. Se valoraron los resultados durante el período de observación del programa (medidas basales de los resultados), y 3 meses y 1 año después de terminada la rehabilitación. Se determinaron entonces los cambios
\end{abstract}


Langelaan, M., Boer, M.R. de, Nispen, R.M.A. van, Wouters, B., Moll, A.C., Rens, G.H.M.B. van. Change in quality of life after rehabilitation: prognostic factors for visually impaired adults.

ocurridos en los valores de las cuatro variables dependientes, y mediante análisis aleatorios de coeficientes se evaluó la relación longitudinal entre la calidad de vida relativa a la visión, por un lado, y entre los factores pronóstico, por el otro. Al comparar, mediante la escala de Salud Mental y Dependencia, los puntaje de los valores obtenidos 1 año después de la rehabilitación con los puntajes iniciales se halló una mejoría importante. En el caso de los participantes que recibieron tratamiento de rehabilitación, la edad pareció ser una factor pronóstico importante para todas las variables. Además, los puntajes relativos al funcionamiento de la visión, y al momento de aparición del trastorno visual, fueron factores pronóstico de las variables «dolor» y «molestias». Los resultados indican que sólo la edad fue un factor pronóstico de todas los indicadores de la calidad de vida. Las investigaciones futuras deben incluir en sus objetivos la confirmación de estos resultados. Por último, estos resultados deben utilizarse como base para realizar ajustes al programa de rehabilitación.

\begin{abstract}
L'objectif général de la rééducation pour les adultes souffrant de déficience visuelle est d'améliorer la qualité de vie et la participation (à la vie sociale). Cette étude avait pour objectifs de déterminer les résultats au court et au long terme d'un programme de rééducation complet sur la qualité de vie des adultes malvoyants et d'établir les facteurs pronostiques de base responsables des différences entre les résultats de certains groupes de patients. Le questionnaire a été administré à 129 adultes malvoyants (âge moyen 42,1 ans). La qualité de vie a été mesurée par le truchement du questionnaire de fonctionnement visuel («Visual Functioning Questionnaire»), développé par le National Eye Institute (NEI-VFQ-25). Les mesures ont été effectuées durant le programme d'observation (mesures de référence), et 3 mois et 1 an après la fin de la rééducation. Les changements entre les mesures ultérieures de quatre variables dépendantes ont été évalués, et la relation longitudinale entre la qualité de vie associée à la vision d'une part et, de l'autre, les facteurs de prédiction possibles, a été déterminée au moyen d'analyses de coefficients aléatoires. Lorsqu'on compare les scores des facteurs 1 an après la rééducation avec les évaluations de référence, l'échelle de santé mentale et de dépendance («Mental Health and Dependency») témoigne d'une amélioration significative. Pour les participants ayant bénéficié de rééducation, l'âge semble constituer une variable prédictive pour la prévision de tous les facteurs. En outre, le score de vision fonctionnelle et le moment d'apparition des déficiences visuelles apparaissent comme des agents prédictifs du facteur «douleur et inconfort». Les résultats indiquent que seul l'âge est un élément prédictif pour tous les aspects de la qualité de vie. Les recherches futures devront chercher à confirmer ces résultats. À terme, ces résultats devront déboucher sur des ajustements du programme de rééducation.
\end{abstract}


Langelaan, M., Boer, M.R. de, Nispen, R.M.A. van, Wouters, B., Moll, A.C., Rens, G.H.M.B. van. Change in quality of life after rehabilitation: prognostic factors for visually impaired adults.

International Journal of Rehabilitation Research: 2009, 32(1), 12-19

\section{INTRODUCTION}

The overall aim of rehabilitation is to improve the quality of life of the patient (Watson, 2001; Heine and Browning, 2002). So far, rehabilitation of visually impaired persons has mainly been based on many years' experience. Over the past 510 years the call for scientific evidence of rehabilitation has, however, become stronger. Several outcome studies in the field of low vision rehabilitation have been present (Nilsson, 1990; McIlwaine et al., 1991; Van Rens et al., 1991; Leat et al., 1994; Bischoff, 1995; Shuttleworth et al., 1995; Harper et al., 1999; Scott et al., 1999; McCabe et al., 2000; Soong et al., 2001; Hartong et al., 2004; Jones and Troscianko, 2006). Most of these studies have focused on objective tasks or specific measures for functional ability such as reading speed, (Nilsson, 1990; Leat et al., 1994) walking speed, (Soong et al., 2001; Hartong et al., 2004; Jones and Troscianko, 2006) frequency, and use of low vision aids (McIlwaine et al., 1991; Van Rens et al., 1991; Leat et al., 1994; Bischoff, 1995), or patient satisfaction with the services (McIlwaine et al., 1991; Shuttleworth et al., 1995; Scott et al., 1999). These measures may not capture all important aspects of the individual state. Therefore, a more comprehensive measure should be used to evaluate the outcome of low vision rehabilitation. Health-related quality of life has been suggested as a good indicator of this outcome (Raasch et al., 1997; Stelmack, 2001).

As the majority of people with a visual impairment are over 65 years of age, (Resnikoff et al., 2004) the studies that have been conducted have been mainly focused on elderly people (Lund et al., 2000; McCabe et al., 2000; Wolffsohn and Cochrane, 2000; Birk et al., 2004; Reeves et al., 2004; de Boer et al., 2006). The adult population between 18 to 65 years of age consists of a relatively smaller group than the elderly, but are of great interest for different reasons. First, the younger adults have a longer life expectancy meaning they have more life years spent with disability than elderly do. Second, many of them are able to participate in paid or unpaid employment. Third, the costs of the intensive rehabilitation they need are very high.

Outcome studies that focus on quality of life in younger visually impaired adults have not been reported (de Boer et al., 2005; Langelaan et al., 2007b). Furthermore, studies of prognostic factors in the outcome of rehabilitation in an adult visually impaired population have not been carried out. These studies could result in information about certain patient characteristics associated with better or worse outcome. This information can then be used to tailor certain parts of rehabilitation programmes to individuals.

If the underlying factors in the outcome of rehabilitation are known, it will be possible for rehabilitation workers to adjust the programme to the needs of visually impaired adults. A thorough study of the prognostic factors in rehabilitation outcome might thus improve the quality of the rehabilitation programme and consequently the quality of life of the participants.

This study describes the outcome of a comprehensive rehabilitation programme on the quality of life for visually impaired adults. The short-term (3 months after finishing rehabilitation) and long-term outcomes (1 year after finishing 
Langelaan, M., Boer, M.R. de, Nispen, R.M.A. van, Wouters, B., Moll, A.C., Rens, G.H.M.B. van. Change in quality of life after rehabilitation: prognostic factors for visually impaired adults.

International Journal of Rehabilitation Research: 2009, 32(1), 12-19

rehabilitation) are described, as well as prognostic baseline factors responsible for differences in outcomes between certain groups of patients.

\section{METHODS}

\section{Study design and sample selection}

In this prospective cohort study, patients were recruited from the National Rehabilitation Centre for visually impaired adults 'Visio Het Loo Erf', Apeldoorn, The Netherlands. The rehabilitation programme is a multidisciplinary low-vision service that includes optometry, occupational therapy, mobility training, psychological (group) sessions, and social work. The general goal of the rehabilitation programme is to improve or maintain participation in society, independency, and quality of life. Consecutive patients, who participated in an observational programme before to rehabilitation between May 2002 and July 2004, were invited to join the study. The eligibility criteria were age 18 years or older, sufficient cognitive abilities, and sufficient understanding of the Dutch language to understand the Visual Functioning Questionnaire-25 (VFQ-25) questions according to the opinion of a psychological research assistant. This study was approved by the ethics committee of the VU University Medical Centre Amsterdam, The Netherlands.

Measurements were conducted during the observational programme (baseline measurement), and 3 months and 1 year after finishing rehabilitation. After baseline measurement, it appeared that some participants did not follow a rehabilitation programme. As they had the intention to rehabilitate, we decided to leave these participants in this study if possible. The time between baseline and follow-up measurements was estimated from the mean waiting period of other participants and the mean rehabilitation duration (18 weeks). As a result, the time between baseline and the measurement 3 months after rehabilitation was set to 7 months; the time between baseline and the measurement 1 year after rehabilitation was set to 16 months. Therefore, the time between measurements became comparable between the two groups.

A total of 135 patients were eligible for inclusion in the study. Six persons did not participate. Reasons for not participating were weak general health (mainly fatigue) or not being interested in the study. Of the remaining 129 participants (mean age 42.1 years; SD 14.1), 27 refused or were not eligible to participate in the rehabilitation programme. The main reasons for refusing rehabilitation were not enough rehabilitation demand, not physically able to participate in the rehabilitation programme, personal reasons, and death. Patient characteristics for participants who received a comprehensive rehabilitation programme and participants who did not receive a rehabilitation programme are presented in Table 1 . No statistically significant differences were observed for any of the measures on baseline between participants who received and who did not receive a comprehensive rehabilitation programme. 
Langelaan, M., Boer, M.R. de, Nispen, R.M.A. van, Wouters, B., Moll, A.C., Rens, G.H.M.B. van. Change in quality of life after rehabilitation: prognostic factors for visually impaired adults.

International Journal of Rehabilitation Research: 2009, 32(1), 12-19

\section{[TABLE 1$]$}

Not all participants had filled out every measurement (Fig. 1). Thirty-five participants were lost to follow-up after baseline measurements. These persons were significantly younger $(\mathrm{P}=0.02)$ than the other participants.

\section{[FIGURE1]}

\section{Visual Functioning Questionnaire}

Quality of life was measured with the VFQ, developed by the National Eye Institute (NEI-VFQ-25) (Mangione et al, 1998, 2001), in face-to-face interviews. In earlier analyses on the baseline data, we performed an exploratory factor analysis and Rasch analysis on the Dutch version of the VFQ-25 (Langelaan et al., 2007a). The adaptations, which we suggested in the earlier study, will be used in this study to calculate four dependant subscale scores: near activities, distance activities and mobility, mental health and dependency, and pain and discomfort.

\section{Prognostic factors}

At baseline, the following possible prognostic factors were assessed: age, sex, visual acuity, visual field, educational level, living situation, time of onset of visual impairment, comorbidity, and active coping behaviour. The possible prognostic factors were selected in meetings between the researchers from the Vrije Universiteit University Medical Centre and a psychologist from the rehabilitation centre. The important criteria were that the factors would logically seem prognostic and that they could be used to adjust the rehabilitation programme. Most of the prognostic factors that were selected are being routinely assessed at Visio Het Loo Erf as part of the observational programme. Information on age and sex was routinely available for every participant. Visual acuity and visual field were assessed for every participant using Early Treatment of Diabetic Retinopathy Study charts and Goldmann perimetry. A functional vision score (FVS) was calculated for each participant. This FVS (Colenbrander, 1999; Cocchiarella and Andersson, 2001) integrates visual acuity and visual field into one comprehensive score. The FVS ranges from 0 to 100, with 0 referring to a condition of total blindness and 100 referring to normal functional vision. Several studies have presented results that support the use of the FVS over standard measures of visual acuity and visual field (Massof and Fletcher, 2001; Massof, 2002; Fuhr et al., 2003). Activity orientation as a preferred coping behaviour (ACT) was being assessed using the Utrechtse Coping List (Schreurs et al., 1993). The highest possible score of 28 refers to active coping behaviour. The lowest possible score was 7. Comorbidity was assessed by asking the participants if they suffered from any diseases or conditions other than their eye condition.

\section{Statistical analysis}

First, we calculated the change between subsequent measurements of the four dependent variables. Second, the longitudinal relationship between vision-related quality of life on the one hand and possible prediction factors on the other, was evaluated by means of random coefficient analyses. We made two separate models: one model for participants who received a rehabilitation programme and a second model for all participants, also including participants who did not undergo the rehabilitation programme. In longitudinal studies, the repeated measurements are 
Langelaan, M., Boer, M.R. de, Nispen, R.M.A. van, Wouters, B., Moll, A.C., Rens, G.H.M.B. van. Change in quality of life after rehabilitation: prognostic factors for visually impaired adults. International Journal of Rehabilitation Research: 2009, 32(1), 12-19

correlated and clustered within the individuals and the measurement (two-level model). Random coefficient analysis takes into account that the repeated observations for one participant are dependent of each other. It does not require complete data sets and both the number of observations per individual and the time between observations may vary. The random coefficient analyses were performed with MLwiN (Rashbash et al., 2000). The intercept was assumed to be randomly distributed between participants. The iterative generalized least-squares algorithm was used to estimate the regression coefficients (Twisk, 2003).

Two-level models were fitted for each of the four outcome variables separately. We used the approach 'analysis of covariance' to correct for the phenomenon 'regression to the mean'. In the analysis of covariance, a correction was made for the baseline value of the outcome variable. Time was constituted as an independent covariate, because of the unequally spaced time points of measurement. Additionally, each model started with eight regression coefficients for potential predictive variables: age, sex, FVS, comorbidity, educational level, social status, time of onset of visual impairment, and ACT. This longitudinal model is presented below:

VFQ factor score $=[\text { beta }]_{0}+[\text { beta }]_{1} \times$ time $+[\text { beta }]_{3} \times($ factor score $)_{\mathrm{t}=1}+[\text { beta }]_{4} \times$ rehabilitation $+[\text { beta }]_{5} \times$ age $+[\text { beta }]_{6} \times$ sex $+[\text { beta }]_{7} \times \mathrm{FVS}+[\text { beta }]_{8} \times \mathrm{com}$ orbidity $+[\text { beta }]_{9} \times$ education $+[\text { beta }]_{10} \times$ social $+[\text { beta }]_{11} \times$ onset $+[\text { beta }]_{12} \times$ ACT

The likelihood ratio test was used to evaluate the necessity for allowing random regression coefficients into the model, whereas the Wald test was used to obtain a $\mathrm{P}$ value of the prediction variable into the model. In the full model, for each of the predictor variables the importance was evaluated for the situation with and without a random slope. After this was done for all predictor variables in the model, we excluded variables from the model in a backward stepwise fashion, where a $\mathrm{P}$ value less than or equal to 0.10 provided a guideline for a variable to remain in the model. This procedure was repeated until all independent variables in the model were significant. For all other tests, a two-tailed significance level of 0.05 was used.

\section{RESULTS}

The longitudinal development of the scores on the four factors of the VFQ-25 is shown in Fig. 2. If the factor scores 1 year after rehabilitation were compared with baseline scores, the Mental Health and Dependency scale showed a significant improvement. All other factors also showed improved quality of life, although these changes were not significant. Participants showed improvement on all factors of the VFQ-25 3 months after rehabilitation compared with baseline, although the improvement was only significant on the Distance Activities and Mobility and on the Mental Health and Dependency scale. No significant changes could be detected 1 year after finishing rehabilitation compared with 3 months after rehabilitation. The Near Activities scale showed a slight improvement, whereas the other scales showed a slight deterioration in quality of life.

[FIGURE 2] 
Langelaan, M., Boer, M.R. de, Nispen, R.M.A. van, Wouters, B., Moll, A.C., Rens, G.H.M.B. van. Change in quality of life after rehabilitation: prognostic factors for visually impaired adults.

International Journal of Rehabilitation Research: 2009, 32(1), 12-19

Table 2 presents the significant predictor variables of the multivariate random coefficient models of the four factors. For participants who received rehabilitation, age seemed to be a significant prediction variable for all factors. Higher age corresponded with a worse quality of life after rehabilitation for three subscales compared with an earlier measurement. On the Pain and Discomfort subscale, older people had better quality of life after rehabilitation.

\section{[TABLE 2]}

Additionally, FVS, and time of onset of visual impairment were predictors for the factor 'Pain and Discomfort'. Participants with a lower FVS had better quality of life than persons with better visual function. If the onset of the visual impairment was before the age of 12 years, the participants had fewer problems with pain and discomfort after rehabilitation.

For the model that includes all participants, some different predictive variables were found compared with the earlier described model. There were no predictive variables for the factors Near Activities, Distance Activities and Mobility, and Mental Health and Dependency. Age, FVS, and time of onset of the visual impairment were predictive variables in the change of quality of life for the Pain and Discomfort factor.

\section{DISCUSSION}

\section{Differences in vision-related quality of life between baseline and follow-up measurements}

Our results indicate that changes in vision-related quality of life between baseline and different follow-up measurements were generally small. Although the quality of life on the Near Activities subscale slightly decreased, the quality of life on the other subscales slightly improved. Small changes were also found by De Boer et al. (2006). They reported small changes in the quality of life in elderly patients 1 year after a programme in an outpatient rehabilitation centre. Our results, however, were in contrast to the study by Stelmack et al. (2002), who reported a significant increase in visual ability after completing a rehabilitation programme. Stelmack et al. (2002) had their follow-up measurement at the conclusion of the rehabilitation programme, before discharge. In addition to the difference in the age of the study population, this might indicate that positive outcomes of rehabilitation programmes we might have had in our sample were not sustained. Before discharge, patients might experience fewer difficulties in their activities of daily living, because they are living in the safe and mostly adapted environment of the rehabilitation centre. Their home environment is often less physically and socially adapted to persons with visual impairments. Therefore, patients might experience more problems in their home environment than in the rehabilitation centre. Another explanation for the small changes in quality of life might be that most of the items of the VFQ-25 are not very sensitive to change. Stelmack et al. (2002) found only four items that were sensitive to change in elderly patients. Three of these items were included in our Near Activities subscale, and the other item was included in the Distance Activities and 
Langelaan, M., Boer, M.R. de, Nispen, R.M.A. van, Wouters, B., Moll, A.C., Rens, G.H.M.B. van. Change in quality of life after rehabilitation: prognostic factors for visually impaired adults.

International Journal of Rehabilitation Research: 2009, 32(1), 12-19

Mobility subscale. Other items (e.g. noticing objects off to the side while walking along) are not very sensitive to change through rehabilitation activities.

\section{Prognostic factors for quality of life after rehabilitation}

In the longitudinal multiple regression analyses, we used the quality of life factor scores on three time measurements as dependent variables while correcting for the baseline scores of these factors. This allowed us to correct for regression to the mean (Twisk and Proper, 2004). The outcome of these regression analyses can be interpreted as adjusted change scores for quality of life after rehabilitation. Therefore, the independent variables were possible predictive variables for change in quality of life.

We found that age was a predictor for all four domains of the VFQ-25. In the pain and discomfort domain, elderly participants experienced fewer problems than did younger participants. The opposite is true for other domains. It could be that the contents of the rehabilitation programme did not fully fit in with the rehabilitation needs of older participants, and therefore affected the quality of life in a different way. The rehabilitation needs were, however, not assessed in a systematic way before rehabilitation. Therefore, we could not add rehabilitation needs as a possible predictor of the model. It might have been that rehabilitation needs was a better predictor for change in quality of life than age.

For the pain and discomfort domain, FVS and time of onset of visual impairment were also predictive variables. Participants with a better functional vision experienced more pain and discomfort in or around the eyes than participants with a worse functional vision. It could be that persons with lower functional vision had more benefit from the strategy advice (e.g. the use of other sense organs) and low vision aids provided by the rehabilitation programme. Participants with better functional vision may rely much more on their residual visual capacities, which caused more pain and discomfort in or around the eyes. We, however, did not measure the use of low vision aids or the use of residual visual capacities during activities of daily living.

Participants with an onset of their visual impairment after the age of 12 years had more problems with pain and discomfort in or around the eyes. Patients with an early onset of visual impairment were not significantly younger and they did not have better functional vision than patients with late onset. It might be that persons with late onset of their visual impairment had already received advice on the use of their residual visual capacities and were in possession of useful low vision aids. Therefore, they could not benefit from these rehabilitation contents. It might not be possible for them to improve on the domain pain and discomfort with the current rehabilitation programme.

Another explanation could be that persons with late onset of visual impairment suffer from more (chronic) diseases or conditions. In this study population, the number of persons with comorbidity is relatively high. Although it was emphasized during the interviews that the participant should only rate the pain related to their visual impairment, this might be difficult in the presence of other diseases. 
Langelaan, M., Boer, M.R. de, Nispen, R.M.A. van, Wouters, B., Moll, A.C., Rens, G.H.M.B. van. Change in quality of life after rehabilitation: prognostic factors for visually impaired adults.

International Journal of Rehabilitation Research: 2009, 32(1), 12-19

\section{Methodological limitations}

The proposed study was a prospective cohort study. Ultimately, a randomized controlled trial on the effectiveness of an alternative rehabilitation programme would be preferable. We, however, could not include a placebo or no treatment group into this study, because of ethical reasons. It would be unethical to withhold patients from a rehabilitation programme. The participants who did not receive a rehabilitation programme after baseline measurement, were not different from the participants who received rehabilitation on baseline variables. The reasons for refusing rehabilitation might have, however, influenced the short-term and long-term outcome.

Although the cohort study was dictated, there were some problems using this design in the study. First, a possible bias in the proposed study could be induced by the Hawthorne effect. The Hawthorne effect is the effect that the scores of the participants in the study were influenced by the fact that the participants know they are under observation. This effect could apply in every sort of research, but quality of life research, where the outcome measures are of a subjective nature, seems especially vulnerable to this effect (Bouchet et al., 1996). A real solution for this problem is, however, not available. The only thing that would be effective is to have people who have to fill out the questionnaires without knowing that they are part of this study. This would also mean that informed consent could not be obtained. It is apparent that this would have been neither ethical nor acceptable to carry out in this study.

A second problem of using a cohort study was the possible placebo effect. The participants' answers on the questionnaires could be influenced by the expectancy that they had on the rehabilitation programme and by the intense contact between the participant and the rehabilitation workers. This effect was, however, a 'real' effect of the rehabilitation programme and would also exist without the research being done.

A limitation of this study was the possible lack of statistical power. A guideline for the use of multiple regression analysis is that no more than ten variables are examined (Altman, 1991). Sufficient statistical power for eight possible predictive variables in the model and a minimum of 80 participants were required. We assumed a nonresponse of $10 \%$ and a dropout rate of $10 \%$ at 3 months follow-up and also at 1 year follow-up; the number of clients that were needed to enroll in the rehabilitation programme was 125 . It, however, appeared that 27 participants did not enroll in the rehabilitation programme. A larger sample of participants would have increased the statistical power, and possibly would have led to more statistically significant results or other predictive variables.

In conclusion, our results indicate that only age was a predictor for all domains of quality of life. As the explanation for the results concerning age are not yet fully understood and because prognostic models tended not to be very stable, future research should be aimed at confirming our results. Ultimately, these findings should lead to adjustments in the rehabilitation programme, which should be tested in a randomized way. We, however, could not include a placebo or a no treatment group in this study because of ethical reasons. It would be unethical to withhold patients from a rehabilitation programme. 
Langelaan, M., Boer, M.R. de, Nispen, R.M.A. van, Wouters, B., Moll, A.C., Rens, G.H.M.B. van. Change in quality of life after rehabilitation: prognostic factors for visually impaired adults. International Journal of Rehabilitation Research: 2009, 32(1), 12-19

\section{Acknowledgements}

This research was supported by ZON-MW - The Netherlands Organisation for Health Research and Development Grant no. 943-01-002.

\section{REFERENCES}

Altman DG 1991. Practical statistics for medical research. 1st ed. London: Chapman \& Hall. Birk T, Hickl S, Wahl HW, Miller D, Kammerer A, Holz F, et al. 2004. Development and pilot evaluation of a psychosocial intervention program for patients with age-related macular degeneration. Gerontologist 44:836-843.

Bischoff P 1995. Long-term results of low vision rehabilitation in age-related macular degeneration. Doc Ophthalmol 89:305-311.

Bouchet C, Guillemin F, Briancon S 1996. Nonspecific effects in longitudinal studies: impact on quality of life measures. J Clin Epidemiol 49:15-20.

Cocchiarella L, Andersson G 2001. The visual system. In: Andersson G, Cocchiarella L, editors. Guides to the evaluation of permanent impairment. 5th ed. Chicago, III: American Medical Association. pp. 277-304.

Colenbrander A 1999. Guide for the evaluation of visual impairment. San Francisco: International Society for Low Vision Research and Rehabilitation.

De Boer MR, Langelaan M, Jansonius NM, Van Rens GHMB 2005. Evidence-based guidelines on the referral of visually impaired persons to low vision services. Eur J Ophthalmol 15:400-406.

De Boer MR, Twisk J, Moll AC, Volker-Dieben HJ, de Vet HC, van Rens GHMB 2006. Outcomes of low-vision services using optometric and multidisciplinary approaches: a nonrandomized comparison. Ophthalmic Physiol Opt 26:535-544.

Fuhr PSW, Holmes LD, Fletcher DC, Swanson MN, Kuyk TK 2003. The AMA Guides functional vision score is a better predictor of vision-targeted quality of life than traditional measures of visual acuity or visual field extent. Vis Impairment Res 5:137-146.

Harper R, Doorduyn K, Reeves B, Slater L 1999. Evaluating the outcomes of low vision rehabilitation. Ophthalmic Physiol Opt 19:3-11.

Hartong DT, Jorritsma FF, Neve JJ, Melis-Dankers BJ, Kooijman AC 2004. Improved mobility and independence of night-blind people using night-vision goggles. Invest Ophthalmol Vis Sci 45:1725-1731.

Heine C, Browning CJ 2002. Communication and psychosocial consequences of sensory loss in older adults: overview and rehabilitation directions. Disabil Rehabil 24:763-773.

Jones T, Troscianko T 2006. Mobility performance of low-vision adults using an electronic mobility aid. Clin Exp Optom 89:10-17.

Langelaan M, van Nispen RMA, Knol DL, Moll AC, de Boer MR, Wouters B, van Rens GHMB 2007a. Visual Functioning Questionnaire: re-evaluation of psychometric properties for a group of working age adults. Optom Vis Sci 84:775-784.

Langelaan M, van Nispen RMA, van Rens GHMB 2007b. Quality of life after rehabilitation for visual impairments. Cochrane Database Syst Rev. (in press).

Leat SJ, Fryer A, Rumney NJ 1994. Outcome of low vision aid provision: the effectiveness of a low vision clinic. Optom Vis Sci 71:199-206. Ovid Full Text

Lund R, Dietrichson J, Stuen C, Arditi A, Horowitz A, Lang MA, et al. 2000. Rehabilitation of people with visual impairments and quality of life. In: Stuen C, et al., editors. Vision rehabilitation-assessment, intervention and outcomes. Lisse: Swets and Zeitlinger Publishers. pp. 780-785.

Mangione CM, Berry S, Spritzer K, Janz NK, Klein R, Owsley C, Lee PP 1998. Identifying the content area for the 51-item National Eye Institute Visual Function Questionnaire: results from focus groups with visually impaired persons. Arch Ophthalmol 116:227-233. Mangione CM, Lee PP, Gutierrez PR, Spritzer K, Berry S, Hays RD 2001. Development of the 25-item National Eye Institute Visual Function Questionnaire. Arch Ophthalmol 119:1050-1058.

Massof RW 2002. The measurement of vision disability. Optom Vis Sci 79:516-552. Ovid Full Text

Massof RW, Fletcher DC 2001. Evaluation of the NEI visual functioning questionnaire as an interval measure of visual ability in low vision. Vis Res 41:397-413. 
Langelaan, M., Boer, M.R. de, Nispen, R.M.A. van, Wouters, B., Moll, A.C., Rens, G.H.M.B. van. Change in quality of life after rehabilitation: prognostic factors for visually impaired adults.

International Journal of Rehabilitation Research: 2009, 32(1), 12-19

McCabe P, Nason F, Demers TP, Friedman D, Seddon JM 2000. Evaluating the effectiveness of a vision rehabilitation intervention using an objective and subjective measure of functional performance. Ophthalmic Epidemiol 7:259-270.

Mcllwaine GG, Bell JA, Dutton GN 1991. Low vision aids-is our service cost effective? Eye 5 (Pt 5):607-611.

Nilsson UL 1990. Visual rehabilitation with and without educational training in the use of optical aids and residual vision. A prospective study of patients with advanced age-related macular degeneration. Clin Vis Sci 6:3-10.

Raasch TW, Leat SJ, Kleinstein RN, Bullimore MA, Cutter GR 1997. Evaluating the value of low-vision services. J Am Optom Assoc 68:287-295.

Rashbash J, Browne W, Goldstein H, Yang M, Plewis I, Healy M, et al. 2000. A user's guide to MLwiN. London, UK: Centre for Multilevel Modelling.

Reeves BC, Harper RA, Russell WB 2004. Enhanced low vision rehabilitation for people with age related macular degeneration: a randomised controlled trial. Br J Ophthalmol 88:14431449.

Resnikoff S, Pascolini D, Etya'ale D, Kocur I, Pararajasegaram R, Pokharel GP, Mariotti SP 2004. Global data on visual impairment in the year 2002. Bull World Health Organ 82:844851.

Schreurs PJG, Willige GVD, Brosschot JF, Tellegen B, Graus GHM 1993. Handleiding Utrechtse Coping Lijst UCL (herziene versie). Lisse: Zwets \& Zeitlinger.

Scott IU, Smiddy WE, Schiffman J, Feuer WJ, Pappas CJ 1999. Quality of life of low-vision patients and the impact of low-vision services. Am J Ophthalmol 128:54-62.

Shuttleworth GN, Dunlop A, Collins JK, James CR 1995. How effective is an integrated approach to low vision rehabilitation? Two year follow up results from south Devon. $\mathrm{Br} \mathrm{J}$ Ophthalmol 79:719-723.

Soong GP, Lovie-Kitchin JE, Brown B 2001. Does mobility performance of visually impaired adults improve immediately after orientation and mobility training? Optom Vis Sci 78:657666. Ovid Full Text

Stelmack J 2001. Quality of life of low-vision patients and outcomes of low-vision rehabilitation. Optom Vis Sci 78:335-342. Ovid Full Text

Stelmack JA, Stelmack TR, Massof RW 2002. Measuring low-vision rehabilitation outcomes with the NEI VFQ-25. Invest Ophthalmol Vis Sci 43:2859-2868.

Twisk JWR 2003. Applied longitudinal data analysis for epidemiology. Cambridge, UK: Cambridge University Press.

Twisk J, Proper K 2004. Evaluation of the results of a randomized controlled trial: how to define changes between baseline and follow-up. J Clin Epidemiol 57:223-228.

Van Rens GHMB, Chmielowski RJ, Lemmens WA 1991. Results obtained with low vision aids. A retrospective study. Doc Ophthalmol 78:205-210.

Watson GR 2001. Low vision in the geriatric population: rehabilitation and management. J Am Geriatr Soc 49:317-330.

Wolffsohn JS, Cochrane AL 2000. Design of the low vision quality-of-life questionnaire (LVQOL) and measuring the outcome of low-vision rehabilitation. Am J Ophthalmol 130:793-802. 
Langelaan, M., Boer, M.R. de, Nispen, R.M.A. van, Wouters, B., Moll, A.C., Rens, G.H.M.B. van. Change in quality of life after rehabilitation: prognostic factors for visually impaired adults. International Journal of Rehabilitation Research: 2009, 32(1), 12-19

TABLES AND FIGURES

Table 1 Baseline characteristics of the participants

\begin{tabular}{|c|c|c|c|c|}
\hline Variables & $\begin{array}{l}\text { All participants } \\
\qquad(n=129)\end{array}$ & $\begin{array}{l}\text { Participants who received } \\
\text { rehabilitation }(n=102)\end{array}$ & $\begin{array}{l}\text { Participants who did not } \\
\text { receive rehabilitation } \\
\qquad(n=27)\end{array}$ & $P$ value ${ }^{a}$ \\
\hline \multicolumn{5}{|l|}{ VFQ-25 } \\
\hline Near activities; Mean (SD) & $14.3(3.6)$ & $14.5(3.4)$ & $13.3(4.2)$ & 0.14 \\
\hline Distance activities and mobility; Mean (SD) & $17.5(3.9)$ & $7.7(3.6)$ & $16.5(4.9)$ & 0.26 \\
\hline Mental health and dependency; Mean (SD) & $13.7(3.3)$ & $13.9(3.2)$ & $12.7(3.5)$ & 0.07 \\
\hline Pain and discomfort; Mean (SD) & $6.1(6.0)$ & $6.2(1.9)$ & $5.5(2.4)$ & 0.13 \\
\hline Age (years); Mean (SD) & $42.2(14.1)$ & $41.6(14.2)$ & $44.7(13.8)$ & 0.32 \\
\hline Sex; \% male & 44.2 & 41.2 & 55.6 & 0.18 \\
\hline Education & & & & 0.94 \\
\hline No education or primary education (\%) & 13.2 & 13.7 & 11.1 & \\
\hline Secondary education (\%) & 69.0 & 68.6 & 70.4 & \\
\hline Tertiary education (\%) & 17.8 & 17.6 & 18.5 & \\
\hline Social status & & & & 0.95 \\
\hline Living alone (\%) & 45.0 & 45.1 & 44.4 & \\
\hline Living with others (\%) & 55.0 & 54.9 & 55.6 & \\
\hline Comorbid condition; $\%$ yes & 60.5 & 56.9 & 74.1 & 0.10 \\
\hline $\begin{array}{l}\text { Time of onset of visual impairment; } \% \text { after } 12 \text { years } \\
\text { of age }\end{array}$ & 74.4 & 73.5 & 77.8 & 0.65 \\
\hline Active coping behaviour; Mean (SD) & $19.0(16.8-21.0)$ & $19.0(17.0-21.0)$ & $19.0(15.8-22.3)$ & 0.72 \\
\hline FVS; median (IQ) & $20.0(7.1-39.5)$ & $19.5(5.2-37.0)$ & $24.8(12.8-44.4)$ & 0.24 \\
\hline Primary diagnosis & & & & 0.64 \\
\hline $\begin{array}{l}\text { Macula degeneration or other macular } \\
\text { disorders (\%) }\end{array}$ & 9.3 & 8.8 & 11.1 & \\
\hline $\begin{array}{l}\text { Diabetic retinopathy or other retinal vascular } \\
\text { diseases }(\%)\end{array}$ & 6.2 & 6.9 & 3.7 & \\
\hline Other retinal disorders $(\%)$ & 24.0 & 24.5 & 22.2 & \\
\hline Anterior segment or other refractive disorders $(\%)$ & 7.8 & 9.8 & 0.0 & \\
\hline Glaucoma or other optic neuropathy (\%) & 20.2 & 18.6 & 25.9 & \\
\hline $\begin{array}{l}\text { Cerebrovascular accident or (traumatic) brain } \\
\text { injury (\%) }\end{array}$ & 17.1 & 15.7 & 22.2 & \\
\hline Other diagnoses $(\%)$ & 15.5 & 15.7 & 14.8 & \\
\hline
\end{tabular}

a Differences in mean were examined with $t$-test; the difference in median was examined with Mann-Whitney; difference in frequencies were examined with $\chi^{2}$-tests FVS, Functional Vision Score; IO, interquartile range; VFO, Visual Functioning Questionnaire. 
Langelaan, M., Boer, M.R. de, Nispen, R.M.A. van, Wouters, B., Moll, A.C., Rens, G.H.M.B. van. Change in quality of life after rehabilitation: prognostic factors for visually impaired adults. International Journal of Rehabilitation Research: 2009, 32(1), 12-19

Fig. 1

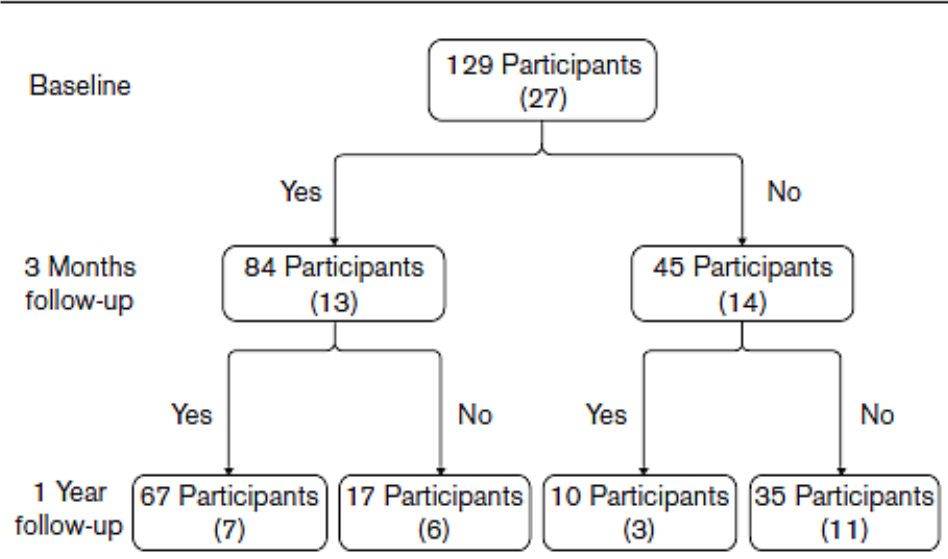

Final working data set of visually impaired adults. The numbers reflect participants who did (Yes) or did not (No) fill out the questionnaires at the specific measurement. The numbers in parentheses reflect the participants who did not receive rehabilitation. For example, 77 $(67+10)$ participants filled out the questionnaire to assess long-term outcome, of which $10(7+3)$ participants did not follow a rehabilitation programme.

Fig. 2

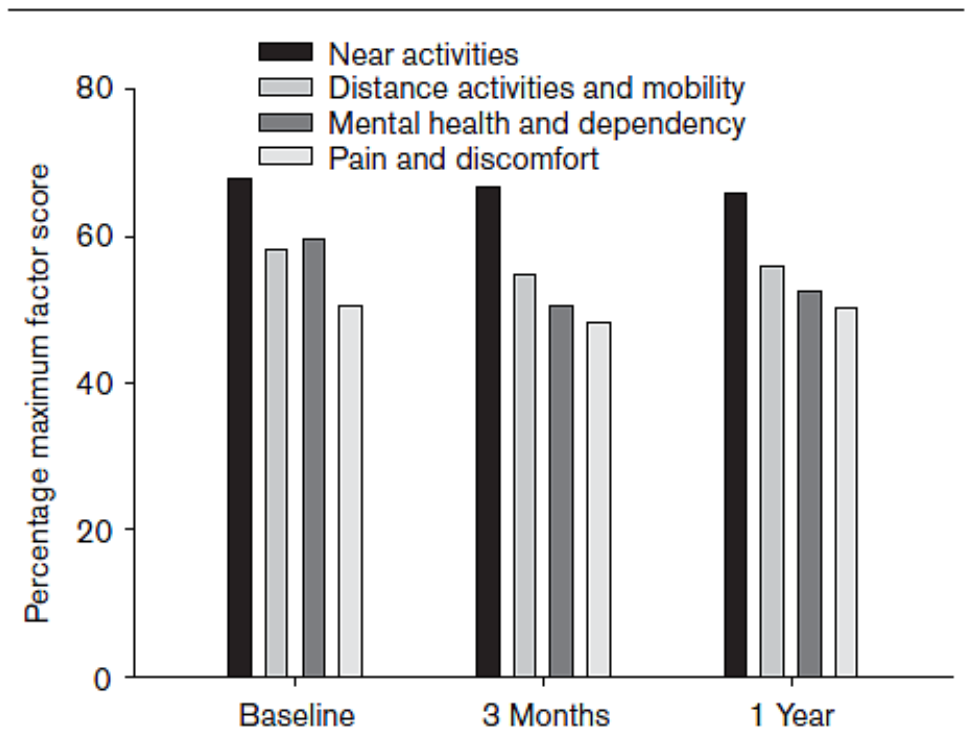

Percentage of maximum factor scores of all participants from three repeated measurements for each Visual Functioning Questionnaire-25 factor. 
Langelaan, M., Boer, M.R. de, Nispen, R.M.A. van, Wouters, B., Moll, A.C., Rens, G.H.M.B. van. Change in quality of life after rehabilitation: prognostic factors for visually impaired adults.

International Journal of Rehabilitation Research: 2009, 32(1), 12-19

Table 2 Multivariate regression model for change in quality of life during the first year after rehabilitation $(n=102)$

\begin{tabular}{|c|c|c|c|c|c|c|c|c|c|c|c|c|}
\hline \multirow[b]{2}{*}{ Variables } & \multicolumn{3}{|c|}{ Near activities } & \multicolumn{3}{|c|}{ Distance activities and mobility } & \multicolumn{3}{|c|}{ Mental health and dependency } & \multicolumn{3}{|c|}{ Pain and discomfort } \\
\hline & $\begin{array}{c}\text { Corrected for } \\
\text { baseline } \\
\beta \text { (SE) }\end{array}$ & $\begin{array}{c}\text { All predictors } \\
\beta \text { (SE) }\end{array}$ & $\begin{array}{c}\text { Relevant } \\
\text { predictors } \\
\beta \text { (SE) }\end{array}$ & $\begin{array}{l}\text { Corrected for } \\
\text { baseline } \\
\beta \text { (SE) }\end{array}$ & $\begin{array}{c}\text { All predictors } \\
\beta \text { (SE) }\end{array}$ & $\begin{array}{c}\text { Relevant } \\
\text { predictors } \\
\beta \text { (SE) }\end{array}$ & $\begin{array}{c}\text { Corrected for } \\
\text { baseline } \\
\beta \text { (SE) }\end{array}$ & $\begin{array}{c}\text { All predictors } \\
\beta \text { (SE) }\end{array}$ & $\begin{array}{c}\text { Relevant } \\
\text { predictors } \\
\beta \text { (SE) }\end{array}$ & $\begin{array}{c}\text { Corrected for } \\
\text { baseline } \\
\beta \text { (SE) }\end{array}$ & $\begin{array}{c}\text { All } \\
\text { predictors } \\
\beta \text { (SE) }\end{array}$ & $\begin{array}{c}\text { Relevant } \\
\text { predictors } \\
\beta \text { (SE) }\end{array}$ \\
\hline Intercept & $1.07(0.47)$ & $0.66(0.86)$ & $0.75(0.50)$ & $1.51(0.68)$ & $0.27(1.14)$ & $1.17(0.72)$ & $4.71(0.78)$ & $0.44(1.23)$ & $3.76(0.89)$ & $1.66(0.32)$ & $1.71(0.67)$ & $1.96(0.45)$ \\
\hline Time & $-0.03(0.03)$ & $-0.05(0.03)$ & $-0.03(0.03)$ & $-0.09(0.03)$ & $-0.09(0.03)$ & $-0.09(0.03)$ & $-0.12(0.03)$ & $-0.14(0.03)$ & $-0.12(0.03)$ & $-0.01(0.02)$ & $0.01(0.02)$ & $0.01(0.014)$ \\
\hline Near activities $T 1$ & $0.93(0.03)$ & $0.89(0.04)$ & $0.90(0.03)$ & & & & & & & & & \\
\hline $\begin{array}{l}\text { Distance } \\
\quad \text { activities } T 1\end{array}$ & & & & $0.91(0.04)$ & $0.94(0.04)$ & & & & & & & \\
\hline Mental health $T 1$ & & & & & & & $0.64(0.05)$ & $0.88(0.05)$ & $0.63(0.05)$ & & & \\
\hline $\begin{array}{l}\text { Pain and } \\
\text { discomfort } T 1\end{array}$ & & & & & & & & & & $0.72(0.05)$ & $0.72(0.05)$ & $0.72(0.05)$ \\
\hline Age (years) & & $0.02(0.01)$ & $0.02(0.01)$ & & $0.01(0.01)$ & $0.02(0.01)$ & & $0.01(0.01)$ & $0.03(0.01)$ & & $-0.02(0.01)$ & $-0.02(0.01)$ \\
\hline Sex & & $-0.34(0.23)$ & & & $-0.14(0.26)$ & & & $-0.32(0.32)$ & & & $0.00(0.19)$ & \\
\hline FVS & & $-0.00(0.01)$ & & & $-0.00(0.01)$ & & & $0.00(0.01)$ & & & $0.01(0.01)$ & $0.01(0.004)$ \\
\hline Comorbidity & & $0.08(0.26)$ & & & $0.05(0.28)$ & & & $-0.42(0.37)$ & & & $-0.01(0.22)$ & \\
\hline Education & & $0.11(0.31)$ & & & $0.19(0.33)$ & & & $0.01(0.42)$ & & & $0.21(0.26)$ & \\
\hline Social status & & $-0.02(0.24)$ & & & $-0.05(0.25)$ & & & $-0.17(0.33)$ & & & $-0.01(0.19)$ & \\
\hline Onset & & $-0.06(0.29)$ & & & $0.29(0.31)$ & & & $0.45(0.38)$ & & & $0.29(0.22)$ & $0.33(0.20)$ \\
\hline $\begin{array}{c}\text { Active coping } \\
\text { behaviour }\end{array}$ & & $0.03(0.03)$ & & & $0.02(0.04)$ & & & $0.03(0.05)$ & & & $0.01(0.02)$ & \\
\hline
\end{tabular}

FVS, Functional Vision Score; $T 1$, baseline measurement. 